\title{
PENGARUH PROFITABILITAS, LIKUIDITAS, HUTANG DAN UKURAN PERUSAHAN TERHADAP DIVIDEND PAYOUT RATIO
}

\section{THE INFLUENCE OF PROFITABILITY, LIQUIDITY, DEBT AND COMPANY SIZE ON DIVIDEND PAYOUT RATIO}

\author{
Regina Fricilya D. Yasmin ${ }^{1)}$, Gendro Wiyono²), Ratih Kusumawardhani ${ }^{3)}$ \\ 1,2,3) Universitas Sarjanawiyata Tamansiswa Yogyakarta \\ Jl. Kusumanegara No.157, Muja Muju, Kec. Umbulharjo, Kota Yogyakarta, Daerah Istimewa \\ Yogyakarta 55165 \\ yasminicha4@gmail.com, gendrowiyono@ustjogja.ac.id,ratihkusuma@ustjogja.ac.id
}

\begin{abstract}
ABSTRAK
Tujuan dari makalah ini adalah untuk menguji pengaruh profitabilitas, arus kas, likuiditas, leverage dan ukuran perusahaan terhadap rasio pembayaran dividen. Sampel meliputi 11 perusahaan manufaktur sektor industri barang konsumsi yang terdaftar di Bursa Efek Indonesia (BEI) periode tahun 2016-2019. Kami menggunakan regresi deret waktu (data panel) untuk menguji hipotesis penelitian ini. Hasil penelitian menunjukkan bahwa variabel independen profitabilitas, likuiditas, dan leverage berpengaruh positif dan signifikan terhadap dividend payout ratio; Sedangkan variabel independen arus kas dan ukuran perusahaan berpengaruh negatif dan signifikan terhadap dividend payout ratio.
\end{abstract}

Kata Kunci: Dividend Payout Ratio, Profitabilitas, Likuiditas, Hutang, Ukuran Perusahaan

\begin{abstract}
The aim of this paper was to examined the influence of profitability, cash flow, liquidity, leverage and firm size towards dividend payout ratio. The sample includes 11 manufactur companis in consumer goods industry sector listed in Inodnesia Stock Exchange (IDX) on the year period 2016-2019. We use time series regression (panel data) to test the hypothesis of this study. The results shows that independent variables of profitability, liquidity, and leverage have positive and significant impact in dividend payout ratio; whereas, the independent variables of cash flow and firm size have negative and significant impact on dividend payout ratio.
\end{abstract}

Keywords : Dividend Payout Ratio, Profitabilitas, Likuiditas, Hutang, Ukuran Perusahaan

\section{PENDAHULUAN}

Dividen telah lama menjadi isu penting di kalangan akademisi keuangan menurut Grullon et al. (dikutip oleh Parsian \& Koloukhi, 2014) yang sampai saat ini tetap menjadi salah satu masalah paling kontroversial di bidang manajemen keuangan. Bahkan, menurut Al- Hasan (2013), keputusan dividen menjadi salah satu keputusan keuangan penting perusahaan yang masih menjadi masalah yang diperdebatkan dunia. Sejalan dengan studi yang dilakukan oleh Simbolon \& Sampurno (2017) yang mengatakan bahwa menajer perlu mempertimbangkan keputusan pembayaran dividen karena akan mempengaruh pembiayaan perusahaan di masa depan. Berdasarkan studi terdahulu yang dilakukan di Negara India (John \& Muthusamy, 2010), Thailand (Komrattanapanya \& Suntraruk, 2014), dan Pakistan (Ahmed \& Murtaza, 2015) ditemukan faktor - faktor yang mempegaruhi Dividend Payout Ratio yaitu 
profitabilitas, likuiditas, leverage dan ukuran perusahaan.

Faktor pertama, profitabilitas (Agyei \& Marfo-Yiadom, 2011). Profitabilitas merupakan karakteristik utama yang kuat dan langsung mempengaruhi kebijakan dividen. Studi yang dilakukan oleh Agyei \& Marfo-Yiadom (2011) menunjukkan bahwa adanya hubungan positif antara pembayaran dividen dan profitabilitas. Hasil studi yang sama dilakukan oleh Lin \& Shen (2012) bahwa profitabilitas dan ukuran perusahaan secara signifikan mempengaruhi rasio pembayaran. Sejalan dengan studi yang dilakukan oleh Thanatawee (2013) bahwa pembayaran dividen di perusahaanperusahaan Thailand dipengaruhi oleh profitabilitas. Hasilnya menunjukkan bahwa variabel profitabilitas memiliki efek positif pada kebutusan pembayaran dividen perusahaan.

Disisi lain, terdapat hasil studi terdahulu yang menunjukkan hubungan negatif antara profitabilitas dengan pembayaran dividen. Misalnya, studi yang dilakukan oleh Made Wiradharma Swastyastu, Gede Adi Yuniarta dan Anantawikrama Tungga Atmadja (2014). Studi mereka menemukan bahwa profitabilitas berpengaruh tidak signifikan dan negatif terhadap dividend payout ratio. Hasil yang sama ditunjukkan pada penelitian yang dilakukan oleh Yudha Atmoko, F. Defung dan Irsan Tricahyadinata (2017) yang meneliti pengaruh profitabilitas yang diukur menggunakan return on assets (ROA) pada perusahaan perbankan yang terdaftar di Bursa Efek Indonesia Periode 2011-2015. Hasilnya menunjukkan bahwa ROA berpengaruh negatif dan tidak signifikan.
Faktor kedua, likuiditas (Komrattanapanya \& Suntraruk, 2014). Anil dan Kapoor (2008) menyelidiki faktor penentu rasio pembayaran dividen di Sektor Teknologi Informasi India selama 20002006. Hasilnya menemukan bahwa adanya hubungan positif antara likuiditas yang diukur dengan arus kas, dan rasio pembayaran dividen. Namun, Adi, Zafar, dan Yaseen (2011) berusaha mengidentifikasi faktor penentu pembayaran dividen dari 100 perusahaan yang terdaftar di Bursa Efek Karachi menggunakan arus kas operasi sebagai proksi likuiditas; hasilnya menunjukkan bahwa peningkatan arus kas operasi mengurangi tingkat pembayaran dividen. Hasil yang sama juga ditunjukkan dalam studi yang dilakukan oleh S. Franklin John and K. Muthusamy (2010) bahwa terdapat hubungan negatif antara likuiditas dan dividend payout ratio.

Faktor ketiga, Hutang (John \& Muthusamy, 2010). Debt to Equity Ratio adalah rasio yang menunjukkan persentase penyediaan dana oleh pemegang saham terhadap pemberi pinjaman (Darsono, 2005). Sejalan dengan studi yang dilakukan oleh Amarjit Gill, Nahum Biger dan Rajendra Tibrewela (2010) di Amerika menemukan bahwa debt to equity ratio memiliki pengaruh positif terhadap dividend payout ratio. Agyei \& Marfo-Yiadom (2011) menunjukkan hasil yang sama. Mereka menyatakan bahwa tingkat hutang yang dimiliki oleh bank di Ghana berpengaruh positif terhadap kebijakan pembayaran dividen bank. John \& Muthusamy (2010) dalam penelitannya menemukan bahwa hutang mempunyai hubungan yang negatif dengan rasio pembayaran dividen (DPR). Dimana semakin rendah hutang maka akan semakin 
tinggi rasio pembayaran dividen dan sebaliknya. Studi lain dilakukan Mereka menjelaskan bahwa ketika hutang bertambah akan mengurangi profitabilitas perusahaan dan mengurangi agency cost.

Hasil studi yang dilakukan di Thailand oleh Komrattanapanya \& Suntraruk (2014) menunjukkan hasil yang sama, yaitu adanya hubungan negatif yang signifikan antara hutang dengan rasio pembayaran dividen. Sedangkan, Gill et al. (2010) menemukan bahwa hutang yang diukur menggunakan debt to equity ratio tidak memiliki hubungan yang signifikan terhadap rasio pembayaran dividen pada sampel yang mereka gunakan. Hasil penelitian ini diperkuat oleh Rafique (2012) yang meneliti faktor-faktor yang mempengaruhi rasio pembayaran dividen di pakitstan. Dalam penelitiannya, ia menemukan tidak ada hubungan yang signifikan antara hutang dengan rasio pembayaran dividen.

Berdasarkan uraian dan penjelasan sebelumnya, dapat dikatakan bahwa hasil studi terhadulu masih belum adanya kesepakatan temuan, artinya masih terdapat keberagaman hasil studi tentang fakktorfaktor yang dapat mempengaruhi dpr. Sehingga, penelitian ini bertujuan untuk mengkonfirmasi temuan terhadulu. Fokus penelitian ini pada perusahaan manufaktur sub sektor makanan dan minuman yang terdaftar di Bursa Efek Indonesia (BEI) periode 2016 hingga 2019. Apakah faktorfaktor tersebut dapat mempengaruhi besarnya DPR?

\section{KEBIJAKAN DIVIDEN}

Dividen merupakan salah satu bentuk peningkatan wealth pemegang saham. Investor akan sangat senang apabila mendapatkan tingkat pengembalian investasinya semakin tinggi dari waktu ke waktu. Oleh karena itu, investor potensial memiliki kepentingan untuk mampu memprediksi berapa besar tingkat pemngembalian investasi yang mereka lakukan (Kadir, 2016). Kebijakan dividen menjadi perhatian banyak pihak seperti pemegang saham, kreditor, maupun pihak eksternal lain yang memiliki kepentingan dari iformasi yang dikeluarkan perusahaan. Melalui kebijakan ini perusahaan memberikan sebagian dari keuntungan bersih kepada pemegang saham secara tunai (Brigham dan Houston 2001 dalam Nuringsih (2005)).

Kebijakan pembayaran dividen memiliki dampak terhadap pemegang saham dan perusahaan yang membagikan dividen. Bagi para pemegang saham, pembagian dividen yang relatif stabil dari perusahaan dapat meminimalisir ketidakpastian akan hasil yang diharapkan atas investasi yang dilakukan. Namun, bagi perusahaan penerapan kebijakan ini dapat menjadi suatu permasalahan. Dalam hal ini, pihak manajemen perusahaan dituntut untuk mengambil keputusan yang dapat mangheasilkan keseimbangan antara kepentingan pemegang saham dan perusahaan (Tedja, Suganda, \& Oktariani, 2020).

\section{DIVIDEND PAYOUT RATIO}

Pengukuran kebijakan dividen diproksi oleh dividend payout ratio. Dividend payout ratio adalah perbandingan antara dividen yang dibayarkan dengan laba bersih yang didapatkan dan biasanya disajikan dalam bentuk persentase. Semakin tinggi dividend payout ratio akan menguntungkan pihak investasi, tetapi pada pihak perusahaan akan memperlemah internal financial, karena memperkecil laba 
ditahan. Namun sebaliknya dividend payout ratio semakin kecil akan merugikan para pemegang saham (investor) tetapi internal financial perusahaan semakin kuat (Parica dkk, 2013 dikutip dalam Pasadena (2013)). Menurut Keown dalam (Deitiana, 2020) adalah jumlah dividen yang dibayarkan relatif terhadap pendapatan bersih perusahaan atau pendapatan tiap lembar.

\section{PROFITABILITAS}

Profitabilitas adalah tulang punggung setiap bisnis baik kecil maupun besar. Semua kegiatan operasional tergantung pada laba yang dihasilkan perusahaan. Profitabilitas perusahaan dapat menilai secara tepat sejauh mana tingkat pengembalian yang akan didapat dari aktivitas investasinya. Ketika perusahaan mendapat penghasilan bagus, ia dapat memutuskan untuk menawarkan dividen lebih tinggi kepada pemegang saham yang merupakan pemilik sebenarnya perusahaan (Ahmed \& Murtaza, 2015).

\section{LIKUIDITAS}

Likuiditas merupakan kemampuan perusahaan untuk memenuhi kewajiban jangka pendeknya. Dalam penelitian ini, likuiditas diukur menggunakan current ratio. Nurhayati (2013) mengatakan bahwa current ratio adalah salah satu alat ukur likuiditas yang merupakan kemampuan perusahaan memenuhi kewajiban jangka pendeknya (Current liability) melalui sejumlah kas yang dimiliki perusahaan. Semakin tinggi current ratio menunjukkan kemampuan kas perusahaan untuk memenuhi (membayar) kewajiban jangka pendeknya. Menurut Munawir (2004) dalam Kadir (2016) adalah perbandingan antara jumlah aktiva lancar dengan hutang lancar.

Current ratio merupakan rasio yang menunjukkan tingkat keamanan (margin of safety) kreditur jangka pendek, atau kemampuan perusahaan untuk membayar hutang-hutangnya (Kadir, 2016).

\section{HUTANG}

Hutang merupakan perimbangan penggunaan hutang dengan modal sendiri dalam suatu perusahaan. Dalam penelitian ini hutang menggunakan rasio Debt to Equity Ratio (DER). Debt to equity ratio merupakan rasio perbandingan total hutang dengan total ekuitas perusahaan (Kadek Dwi Mahendra (2016)). Dikutip dalam Yasa \& Wirawati (2016), Marlina dan Clara mengungkapkan peningkatan hutang akan mempengaruhi besar kecilnya laba bersih yang tersedia bagi para pemegang saha termasuk dividen yang diterima karena kewajiban untuk membayar hutang lebih diutamakan daripada pembagian dividen.

\section{UKURAN PERUSAHAAN}

Holder, Langrehr, dan Hexter mengungkapkan bahwa perusahaan besar dapat lebih mudah mengakses modal pasar dan mengumpulkan dana dari pembiayaan eksternal dengan biaya lebih rendah daripada perusahaan kecil. Oleh karena itu, perusahaan besar lebih suka membayar dividen daripada perusahaan kecil (dikutip dalam Komrattanapanya \& Suntraruk, 2014).

Kim \& Gu (2009) menegaskan bahwa perusahaan perhotelan besar adalah perusahaan dewasa dengan sedikit peluang investasi baru. Ketika mereka untung, mereka lebih cenderung membagikan sebagian dari keuntungan mereka sebagai dividen.

\section{HASIL DAN PEMBAHASAN Sifat Penelitian}

Penelitian ini merupakan penelitian kuantitatif yang dituntut menggunakan 
angka, mulai dari pengumpulan data, penafsiran terhadap data tersebut serta penampilan dari hasilnya.

Tabel 1

Variabel dan Definisi Operasional

\begin{tabular}{|l|l|l|}
\hline \multicolumn{1}{|c|}{ Variabel } & \multicolumn{1}{c|}{ Pengukur } & \multicolumn{1}{c|}{ Sumber } \\
\hline $\begin{array}{l}\text { Dividend Payout } \\
\text { Ratio } \text { (Y) }\end{array}$ & \multicolumn{1}{|c|}{$\begin{array}{l}\text { John \& Muthusamy } \\
(2010)\end{array}$} \\
\hline Profitablitas (X1) & $\begin{array}{l}\text { ROA = Laba bersih setelah } \\
\text { pajak / Total Aset x 100\% }\end{array}$ & $\begin{array}{l}\text { Parsian \& Koloukhi } \\
(2014)\end{array}$ \\
\hline Likuiditas (X2) & $\begin{array}{l}\text { Current Ratio = Aktiva } \\
\text { lancar/Hutang Lancar x 100\% }\end{array}$ & $\begin{array}{l}\text { (Komrattanapanya \& } \\
\text { Suntraruk, 2014) }\end{array}$ \\
\hline Hutang(X3) & $\begin{array}{l}\text { DER = Total Utang / Total } \\
\text { Modal Sendiri }\end{array}$ & Gill et al. (2010) \\
\hline $\begin{array}{l}\text { Ukuran Perusahaan } \\
\text { (X4) }\end{array}$ & Size = Total Aset & Nuhu (2014) \\
\hline
\end{tabular}

\section{Populasi dan Sampel}

Populasi dalam penelitian ini adalah perusahaan manufaktur yang listed di Bursa Efek Indonesia (BEI) antara periode 2016 2019. Jumlah populasi ini adalah 140 perusahaan dan tidak semua populasi ini akan menjadi obyek penelitian sehingga perlu dilakukan pengambilan sampel. Adapun teknik sampling yang digunakan adalah purposive sampling, yaitu pemilihan anggota sampel dengan mendasarkan pada kriteria-kriteria tertentu. Kriteria yang digunakan dalam penelitian ini adalah :

1. Perusahaan manufaktur yang terdaftar di BEI sejak tahun 2016 dan tetap terdaftar di BEI hingga tahun 2019 sektor industri barang konsumsi. Hal ini dimaksudkan untuk data yang berkesinambungan.

Tabel 2

Sampel Perusahaan

\begin{tabular}{|r|l|}
\hline \multicolumn{1}{|c|}{ No. } & \multicolumn{1}{|c|}{ Nama Perusahaan Manufaktur Sektor Barang Konsumsi } \\
\hline 1. & Delta Djakarta Tbk (DLTA) \\
\hline 2. & Darya Varia Laboratoria Tbk, PT (DVLA) \\
\hline 3. & Handjaya Mandala Sampoerna (HMSP) \\
\hline 4. & Indofood CBP Sukses Makmur Tbk, PT (ICBP) \\
\hline 5. & Indofood Sukses Makmur Tbk, PT (INDF) \\
\hline
\end{tabular}

Regina Fricilya D. Yasmin, Gendro Wiyono dan Ratih Kusumawardhani

Pengaruh Profitabilitas, Likuiditas, Hutang, dan Ukuran Perusahaan terhadap Dividend Payout Ratio 


\begin{tabular}{|r|l|}
\hline 6. & Kino Indonesia Tbk (KINO) \\
\hline 7. & Multi Bintang Indonesia Tbk, PT (MLBI) \\
\hline 8. & Mayora Indah TBK, PT (MYOR) \\
\hline 9. & Prashida Aneka Niaga Tbk, PT (PSDN) \\
\hline 10 & Sidomuncul Tbk, PT (SIDO) \\
\hline 11 & Mandom Indonesia, PT (TCID) \\
\hline
\end{tabular}

\section{HASIL PENELITIAN}

\section{Analisis Regresi Linier Berganda}

Pengujian pengaruh variable independent terhadap variable dependen dilakukan dengan menggunakan alat analisis regresi linier berganda. Hasil analisis regresi terdapat pada tebel 3 berikut:

Table 3

Hasil Analisis Regresi Linier Berganda

\begin{tabular}{|c|c|c|c|c|c|}
\hline \multirow{2}{*}{ Model } & \multicolumn{2}{|c|}{$\begin{array}{c}\text { Unstandardized } \\
\text { Coefficients }\end{array}$} & $\begin{array}{c}\text { Standardized } \\
\text { Coefficients }\end{array}$ & \multirow{2}{*}{ S } & \multirow{2}{*}{ Sig } \\
\cline { 2 - 5 } & $\mathbf{B}$ & $\begin{array}{c}\text { Std. } \\
\text { error }\end{array}$ & \multirow{2}{*}{ Beta } & & \\
\hline \multicolumn{1}{|c|}{ Constanta } & -2.861 & 11.824 & & -.242 & .810 \\
\hline Profitabilitas $\left(\mathrm{X}_{1}\right)$ & 1.229 & .294 & .457 & 4.173 & .000 \\
\hline Likuiditas $\left(\mathrm{X}_{2}\right)$ & 0.072 & .020 & .530 & 3.645 & .001 \\
\hline Hutang $\left(\mathrm{X}_{3}\right)$ & 27.966 & 7.546 & .542 & 3.706 & .001 \\
\hline $\begin{array}{l}\text { Ukuran Perusahaan } \\
\left(\mathrm{X}_{4}\right)\end{array}$ & $-1.873 \mathrm{E}^{-12}$ & .000 & -.273 & - & .017 \\
\hline \multicolumn{1}{|c|}{ F } & & 12.9015 & & & \\
\hline \multicolumn{1}{|c|}{ Adj. R Square } & & $\mathbf{0 , 5 2 5}$ & & & \\
\hline \multicolumn{1}{|c|}{ Durbin Watson } & & $\mathbf{1 , 5 2 6}$ & & & \\
\hline
\end{tabular}

\section{Analisis Koefisien Determinasi}

Dari tabel 3 di atas dapat dilihat bahwa adjusted $\mathrm{R}^{2}$ adalah sebesar 0.525 atau $52,5 \%$. Hal ini menujukkan bahwa variabel dividend payout ratio (DPR) dapat dijelaskan oleh variabel independen yaitu profitabilitas, arus kas, likuiditas, hutang dan ukuran perusahaan sebesar 52,5\% sedangkan sisanya $47,5 \%$ dijelaskan oleh faktor-faktor lain diluar model analisis.

\section{Uji Statistik F}

Berdasarkan tabel 3 diatas dapat dilihat bahwa model persamaan ini memiliki tingkat signifikansi sebesar 0,000 lebih kecil dibandingkan dengan alpha 0,05. Hal ini berarti semua variabel independen yang meliputi profitabilitas, arus kas, likuiditas, hutang dan ukurang perusahaan merupakan penjelas yang signifikan terhadap variabel dividend payout ratio (DPR). Oleh karena itu dapat disimpulkan bahwa model regresi dapat digunakan untuk memprediksi pengaruhnya terhadap dividend payout ratio

\section{Uji Statistik t}

Dari hasil pengolahan data menunjukkan persamaan regresi linier berganda sebagai berikut:

$\mathrm{Y}=\mathrm{b}_{0}+\mathrm{b}_{1}$ Profitabilitas- $\mathrm{b}_{2}$ Likuiditas + $\mathrm{b}_{3}$ Hutang $+\mathrm{b}_{4}$ Ukuran Perusahaan $+\mathrm{e}$ Adapun hasil analisis Regresi berganda diperoleh sebagai berikut: 
DPR $=-2,861+1,229 \mathrm{X}_{1}+0,072 \mathrm{X}_{2}+$ $27,966 \mathrm{X}_{3}-1,873 \mathrm{E}-12 \mathrm{X}_{4}$

Berdasarkan tabel 3 dapat disimpulkan bahwa keempat variabel independen yaitu profitabilitas, likuiditas, hutang dan ukuran perusahaan mempunyai nilai probabilitas masing - masing sebesar $0,000,0,001,0,001$ dan 0,17 dimana dikatakan sangat signifikan apabila nilai probabilitas tersebut kurang dari 0,05 atau 5\% sehingga dapat disimpulkan bahwa variabel profitabilitas, likuiditas, hutang dan ukuran perusahaan menunjukkan hasil yang sangat signifikan.

Uji t terhadap variabel profabilitas perusahaan $\left(\mathrm{X}_{1}\right)$, menunjukkan nilai t hitung sebesar 4,173 dan hasil signifikansi yang diperoleh sebesar 0,000 ( $<<1)$, maka secara parsial profabilitas berpengaruh sangat signifikan terhadap dividend payout ratio. Karena koefisien regresi pengaruh profabilitas terhadap dividend payout ratio bertanda positif yaitu 1,229>0, maka hal ini mengindikasikan bahwa pengaruh keduanya berbanding lurus. Semakin tinggi profitabilitas maka akan semakin tinggi juga nilai dividend payout ratio (DPR) dan sebaliknya.

Uji t terhadap variabel likuiditas perusahaan $\left(\mathrm{X}_{1}\right)$, menunjukkan nilai t hitung sebesar 3,645 dan hasil signifikansi yang diperoleh sebesar 0,001 ( $\mathrm{p}<1)$, maka secara parsial likuiditas berpengaruh terhadap dividend payout ratio. Karena koefisien regresi pengaruh likuiditas terhadap dividend payout ratio bertanda positif yaitu $0,072>0$, maka hal ini mengindikasikan bahwa pengaruh keduanya berbanding lurus. Semakin tinggi likuiditas maka akan semakin tinggi juga nilai dividend payout ratio (DPR) dan sebaliknya.
Uji $\mathrm{t}$ terhadap variabel hutang perusahaan $\left(\mathrm{X}_{1}\right)$, menunjukkan nilai t hitung sebesar 3,076 dan hasil signifikansi yang diperoleh sebesar 0,001 $(\mathrm{p}<1)$, maka secara parsial hutang berpengaruh sangat signifikan terhadap dividend payout ratio. Karena koefisien regresi pengaruh hutang terhadap dividend payout ratio bertanda positif yaitu $27,966>0$, maka hal ini mengindikasikan bahwa pengaruh keduanya berbanding lurus. Semakin tinggi hutang maka akan semakin tinggi juga nilai dividend payout ratio (DPR) dan sebaliknya.

Uji $t$ terhadap variabel ukuran perusahaan $\left(\mathrm{X}_{1}\right)$, menunjukkan nilai t hitung sebesar -2,491 dan hasil signifikansi yang diperoleh sebesar 0,017 ( $\mathrm{p}<5)$, maka secara parsial ukuran perusahaan berpengaruh terhadap dividend payout ratio. Karena koefisien regresi pengaruh ukuran perusahaan terhadap dividend payout ratio bertanda negatif yaitu $-1,873 \mathrm{E}-12<0$, maka hal ini mengindikasikan bahwa pengaruh keduanya berbanding terbalik. Semakin tinggi ukuran perusahaan maka akan semakin rendah nilai dividend payout ratio (DPR) dan sebaliknya, semakinkecil ukuran perusahaan maka akan semakin tinggi nilai dividend payout ratio (DPR).

\section{PEMBAHASAN}

\section{Pengaruh Profitabilitas terhadap Dividend Payout Ratio}

Hipotesis pertama adalah apakah profitabilitas berpengaruh positif terhadap dividend payout ratio (DPR) perusahaan manufaktur sektor industri barang konsumsi yang terdaftar di BEI tahun 2016-2019. Hasil penelitian ini membuktikan bahwa variabel profitabilitas memiliki pengaruh positif yang signifikan terhadap dividend payout ratio (DPR). Maka dapat ditarik 
kesimpulan bahwa $\mathrm{H}_{1}$ diterima. Artinya besar kecilnya profitabilitas berpengaruh positif terhadap dividend payout ratio (DPR) perusahaan manufaktur sektor industri barang konsumsi pada tahun 2016-2019.

\section{Pengaruh Likuiditas terhadap Dividend Payout Ratio}

Hipotesis kedua adalah apakah likuiditas berpengaruh negatif terhadap dividend payout ratio (DPR) perusahaan manufaktur sektor industri barang konsumsi yang terdaftar di BEI tahun 2016-2019. Hasil penelitian ini membuktikan bahwa variabel likuiditas memiliki pengaruh positif yang signifikan terhadap dividend payout ratio (DPR). Maka dapat ditarik kesimpulan bahwa $\mathrm{H}_{3}$ ditolak. Artinya besar kecilnya likuiditas berpengaruh positif terhadap dividend payout ratio (DPR) perusahaan manufaktur sektor industri barang konsumsi pada tahun 2016-2019.

\section{Pengaruh Hutang terhadap Dividend Payout Ratio}

Hipotesis ketiga adalah apakah hutang berpengaruh negatif terhadap dividend payout ratio (DPR) perusahaan manufaktur sektor industri barang konsumsi yang terdaftar di BEI tahun 2016-2019. Hasil penelitian ini membuktikan bahwa variabel hutang memiliki pengaruh positif yang signifikan terhadap dividend payout ratio (DPR). Maka dapat ditarik kesimpulan bahwa $\mathrm{H}_{4}$ ditolak. Artinya besar kecilnya hutang berpengaruh positif terhadap dividend payout ratio (DPR) perusahaan manufaktur sektor industri barang konsumsi pada tahun 2016-2019.

\section{Pengaruh Ukuran Perusahaan terhadap Dividend Payout Ratio}

Hipotesis keempat adalah apakah ukuran perusahaan berpengaruh positif terhadap dividend payout ratio (DPR) perusahaan manufaktur sektor industri barang konsumsi yang terdaftar di BEI tahun 2016-2019. Hasil penelitian ini membuktikan bahwa variabel ukuran perusahaan memiliki pengaruh negatif terhadap dividend payout ratio (DPR). Maka dapat ditarik kesimpulan bahwa $\mathrm{H}_{5}$ ditolak. Artinya besar kecilnya hutang berpengaruh negatif terhadap dividend payout ratio (DPR) perusahaan manufaktur sektor industri barang konsumsi pada tahun 20162019.

\section{SIMPULAN}

Penelitian ini bertujuan untuk mengetahui pengaruh profitabilitas, arus kas, likuiditas, hutang dan ukuran perusahaan terhadap dividend payout ratio (DPR) pada perusahaan manufaktur yang terdaftar di Bursa Efek Indonesia (BEI) sektor industri barang konsumsi periode 2016-2019. Berdasarkan hasil analisis, maka kesimpulan yang dapat diambil dari penelitian ini adalah sebagai berikut:

1. Profitabilitas berpengaruh positif dan signifikan terhadap dividend payout ratio (DPR) pada perusahaan manufaktur yang terdaftar di Bursa Efek Indonesia (BEI) sektor industri barang konsumsi periode 2016-2019.

2. Likuiditas berpengaruh positif dan signifikan terhadap dividend payout ratio (DPR) pada perusahaan manufaktur yang terdaftar di Bursa Efek Indonesia (BEI) sektor industri barang konsumsi periode 2016-2019.

3. Hutang berpengaruh positif dan signifikan terhadap dividend payout ratio (DPR) pada perusahaan 
manufaktur yang terdaftar di Bursa Efek Indonesia (BEI) sektor industri barang konsumsi periode 2016-2019.

Ukuran perusahaan berpengaruh negatif dan signifikan terhadap dividend payout ratio (DPR) pada perusahaan manufaktur yang terdaftar di Bursa Efek Indonesia (BEI) sektor industri barang konsumsi periode 2016-2019.

\section{DAFTAR PUSTAKA}

Agyei, S. K., \& Marfo-Yiadom, E. (2011). Dividend Policy and Bank Performance in Ghana. International Journal of Economics and Finance, 3(4), 202207.

https://doi.org/10.5539/ijef.v3n4p202

Ahmed, S., \& Murtaza, H. (2015). Critical Analysis of the Factors Affecting the Dividend Payout: Evidence from Pakistan. International Journal of Economics, Finance and Management Sciences, $3(3), 204$. https://doi.org/10.11648/j.ijefm.20150 303.17

Al- Hasan, A. (2013). The Effect of Dividend Policy on Share Price: An Evaluative Study. IOSR Journal of Economics and Finance, 1(4), 06-11. https://doi.org/10.9790/5933-0140611

Deitiana, T. (2020). Faktor-Faktor Yang Mempengaruhi Kebijakan Dividen. Nominal: Barometer Riset Akuntansi Dan Manajemen, 9(2), 132-149. https://doi.org/10.21831/nominal.v9i2. 30111

Gill, A., Biger, N., \& Tibrewala, R. (2010). Determinants of Dividend Payout Ratios: Evidence from United States. The Open Business Journal, 3(1), 8-14. https://doi.org/10.2174/187491510100 3010008
John, S. F., \& Muthusamy, K. (2010). Leverage, Growth and Profitability as Determinants of Dividend Payout Ratio-Evidence from Indian Paper Industry. Asian Journal of Business Management Studies, 1(1), 26-30.

Kadir, A. (2016). Analisis Faktor-Faktor Yang Mempengaruhi Kebijakan Dividen Pada Perusahaan Credit Agencies Go Public Di Bursa Efek Indonesia. Jurnal Manajemen Dan Akuntansi, 11, 10-20.

Kim, H., \& Gu, Z. (2009). Financial features of dividend-paying firms in the hospitality industry: A logistic regression analysis. International Journal of Hospitality Management, 28(3), 359-366. https://doi.org/10.1016/j.ijhm.2008.12. 003

Komrattanapanya, P., \& Suntraruk, P. (2014). Factors Influencing Dividend Payout in Thailand: A Tobit Regression Analysis. International Journal of Accounting and Financial Reporting, 3(2), 255. https://doi.org/10.5296/ijafr.v3i2.4443

Lin, K. L., \& Shen, C. H. (2012). The impact of corporate governance on the relationship between investment opportunities and dividend policy: An endogenous switching model approach. Asia-Pacific Journal of Financial Studies, 41(2), 125-145. https://doi.org/10.1111/j.20416156.2012.01067.x

Nuhu, E. (2014). Revisiting the Determinants of Dividend Payout Ratios in Ghana. International Journal of Business and Social Science, 5(8), 230-238.

Nurhayati, M. (2013). Profitabilitas, 
Likuiditas Dan Ukuran Perusahaan Pengaruhnya Terhadap Kebijakan Dividen dan Nilai Perusahaan Sektor Non Jasa. Jurnal Keuangan Dan Bisnis, 5(2), 144-153.

Nuringsih, K. (2005). Analisis Pengaruh Kepemilikan Manajerial, Kebijakan Utang, Roa Dan Ukuran Perusahaan Terhadap Kebijakan Dividen: Studi 1995-1996. Jurnal Akuntansi Dan Keuangan Indonesia, 2(2), 103-123. https://doi.org/10.21002/jaki.2005.12

Parsian, H., \& Koloukhi, A. S. (2014). A study on the effect of free cash flow and profitability current ratio on dividend payout ratio: Evidence from Tehran Stock Exchange. Management Science Letters, $\quad 4, \quad 63-70$. https://doi.org/10.5267/j.msl.2013.11.0 33

Pasadena, R. P. (2013). Pengaruh Likuiditas, Leverage, Profitabilitas Dan Ukuran Perusahaan Terhadap Kebijakan Dividen Pada Perusahaan Manufaktur Yang Terdaftar Di Bursa Efek Indonesia. In Skripsi.

Rafique, M. (2012). Factors Affecting Dividend Payout: Evidence From Listed Non-Financial Firms of Karachi
Stock Exchange. Business

Management Dynamics, 1(11), 76-92.

Simbolon, K., \& Sampurno, D. (2017). Analisis Pengaruh Firm Size, DER , Asset Growth , ROE,EPS, Quick Ratio dan Past Dividend terhadap Dividend Payout Ratio. Diponegoro Journal of Management, 6(3), 1-13.

Tedja, I. C., Suganda, T. R., \& Oktariani, F. (2020). Permintaan Investor dan Karakteristik Keuangan terhadap Keputusan Pembayaran Dividen. Jurnal Akuntansi, 12(2), 327-336. https://doi.org/10.28932/jam.v12i2.252 8

Thanatawee, Y. (2013). Ownership Structure and Dividend Policy: Evidence from Thailand. 5(1), 121132.

https://doi.org/10.5539/ijef.v5n1p121

Yasa, kadek dwi mahendra, \& Wirawati, ni gusti putu. (2016). Pengaruh Net Profit Margin, Current Ratio, dan Debt to Equity Ratio pada Dividend Payout Ratio. E-Jurnal Akuntansi Universitas Udayana, 16, 921-950. Retrieved from file://C:/Users/larasatiperbanas/Downl oads/16463-45006-1-PB.pdf 